\title{
Bacterial community structure of mangrove sediments in relation to environmental variables accessed by $16 S$ rRNA gene-denaturing gradient gel electrophoresis fingerprinting
}

\author{
YANYING ZHANG ${ }^{1,2,3,4}$, JUNDE DONG ${ }^{1,2,3}$, BIN YANG ${ }^{1,2,3,4}$, JUAN LING ${ }^{1,2,3,4}$, \\ YOUSHAO WANG ${ }^{1}$ and SI ZHANG ${ }^{1,3}$ \\ ${ }^{1}$ South China Sea Institute of Oceanology, Chinese Academy of Sciences, Guangzhou 510301, P. R. China. \\ ${ }^{2}$ National Experiment Station of Tropical Marine Biology, Sanya, Hainan Island, P. R. China. \\ E-mail: amy0517@gmail.com \\ ${ }^{3}$ Key Laboratory of Marine Bio-resources Sustainable Utilisation (LMB), Guangzhou, Guangdong, P. R. China. \\ ${ }^{4}$ Graduate School of Chinese Academy of Science, Beijing, P. R. China.
}

\begin{abstract}
SUMMARY: Bacterial community structure and the relationship between environmental variables and microbial communities in the surface sediments of tropical mangrove ecosystems were investigated in Sanya, Hainan Island, China. Profiles of bacterial communities were generated using culture-independent PCR-denaturing gradient gel electrophoresis (DGGE), and the results were interpreted with multivariate statistical analysis. Findings suggested that microbial communities varied with sample collection sites and seasons. The samples collected from the same sample sites at the same time had more similar microbial communities except samples SH3 and AB5, which also had unique sediment quality. Canonical correspondence analysis (CCA) revealed that the organic carbon concentration of the sediments accounted for a significant amount of the variability in the bacterial community composition. Phylogenetic analysis was used to identify the major groups of the predominant bacterial phylotypes. 16S rRNA gene-V3 fragments from 17 individual DGGE bands were sequenced and the corresponding bacteria were found in mangrove sediments for the first time based on BLAST results. Predominant bacterial phylotypes clustered with various taxonomic groups, including Proteobacteria, Bacteroidetes, Gemmatimonadetes, Actinobacteria and Firmicutes.
\end{abstract}

Keywords: bacterial community, mangrove sediments, denaturing gradient gel electrophoresis, multivariate statistics.

RESUMEN: ESTRUCTURA DE LA COMUNIDAD BACTERIANA EN SEDIMENTOS DE MANGLARES EN RELACIÓN A VARIABLES MEDIOAMBIENTALES MEDIANTE ANÁLISIS DE FRAGMENTOS DEL GEN I6S RRNA Y ELECTROFORESIS EN GELES DESNATURALIZANTES. - La estructura de la comunidad bacteriana y la relación entre variables ambientales y las comunidades microbianas de la superficie de sedimentos de los ecosistemas tropicales de manglares fueron investigados en Sanya, Hainan Island, China. Los perfiles de las comunidades bacterianas fueron obtenidos utilizando electroforesis de gradiente de gel desnaturalizante (DGGE), cultivo-independiente, y los resultados fueron interpretados con un análisis estadístico multivariante. Los resultados sugerían que las comunidades microbianas variaban con los lugares de muestreo y las estaciones. Las muestras recogidas en el mismo lugar de muestreo y al mismo tiempo tenían comunidades microbianas similares, excepto las muestras SH3 y AB5, que tenían diferente calidad de sedimentos. El análisis de correspondencia (CCA) mostró que la concentración de carbono orgánico en sedimentos explicaba una parte importante de la variabilidad en la composición de la comunidad bacteriana. Los análisis filogenéticos fueron usados para identificar los grupos más importantes de filotipos predominantes de bacterias. Se secuenciaron fragmentos 16 rRNA gene-V3 de 17 bandas individuales de DGGE y las bacterias correspondientes fueron encontradas por primera vez en sedimentos de manglares en base a resultados de BLAST. Los filotipos de bacterias predominantes se agrupaban con varios grupos taxonómicos que incluyen Proteobacteria, Bacteroidetes, Gemmatimonadetes, Actinobacteria y Firmicutes.

Palabras clave: comunidad bacteriana, sedimentos de manglares, electroforesis de gradiente de gel desnaturalizante, analisis estadistico multivariante. 


\section{INTRODUCTION}

Mangrove ecosystems are dominant ecosystems along tropical coastlines. They have important relationships with the regulation and optimisation of tropical marine environments. They are thought to be very important as primary producers of organic matter, providing the base for a large and complex food web. Although mangrove ecosystems are rich in organic matter, in general they are nutrient-deficient, especially with regard to nitrogen and phosphorus (Sengupta and Chaudhuri, 1991; Holguin et al., 1992; Alongi et al., 1993; Vazquez et al., 2000). Microbial activity is responsible for major nutrient transformations within a mangrove ecosystem (Alongi et al., 1993; Holguin et al., 2001). It has been documented that microorganisms play an important role in the productivity, conservation and rehabilitation of mangrove ecosystems (Holguin et al., 2001). Knowledge of microbial community diversity and the relationship between environmental factors and members of bacterial communities in mangrove sediments is important for understanding how the mangrove ecosystems function; this is necessary to formulate effective management and conservation strategies. To understand the community and diversity of bacteria in mangrove ecosystems, isolation and cultivation methods are often used. However, the culturable bacteria are not representative of total community. The major problem of cultivation-based analysis is that only a small part of the bacterial populations can be recovered from the sediments by traditional cultivation techniques (Staley and Konopka, 1985; Amann et al., 1995; Bürgmann et al., 2004). Most environmental bacteria cannot be cultured using current culture-based and traditional methods (Li et al., 2006). Molecular techniques based on culture-independent techniques such as denaturing gradient gel electrophoresis (DGGE), automated ribosomal intergenic spacer analysis (ARISA) and terminal restriction fragment length polymorphism (TRFLP) have provided new tools for genetically identifying bacteria in all kinds of environmental systems, which has enhanced the knowledge of the in situ population structure of bacteria communities ( $\mathrm{Li}$ et al., 2006; Liang et al., 2007; Muckian et al., 2007). As DGGE can separate sequences of the same length with only a base difference, 16S rRNA gene-DGGE fingerprinting is particularly useful as an initial investigation to compare communities and identify the qualitative or most relatively abundant community members (Muyzer et al., 1993).
The objectives of this study were (1) to determine the variability in microbial communities and environmental parameters from different tropical mangrove samples of Sanya Mangrove Nature Reserve, (2) to determine whether environmental variables are related to microbial community variability and (3) to identify the major bacterial phylogenetic groups present in the different samples investigated.

\section{MATERIAL AND METHODS}

Sanya Mangrove Nature Reserve is a typical tropical mangrove ecosystem located at the southernmost part of Hainan Island in China, covering an area of about $250 \mathrm{hm}^{2}$, including Yalong Bay Qingmei, Yulin Bay Hongsha, Sanya River and Linwang Tielu Nature Reserve. The dominating tree species include Rhizophora apiculata, Avicennia marina, Xylocarpus granatum, Rhizophora stylosa, Bruguiera gymnorhiza and Ceriops tagal. The mangrove environment and the mangrove vegetation of Sanya Mangrove Nature Reserve have previously been described by Fu and Li (1999), Mo et al., (1999) and Huang et al., (2007). In this study the samples were collected from the swamp of Sanya Mangrove Nature Reserve. The swamp is inundated by tides twice a day. The mean relative humidity is about $80 \%$, and the annual average air temperature and rainfall are $25.4^{\circ} \mathrm{C}$ and $1279.5 \mathrm{~mm}$, respectively. The two sample collection sites were situated in the Sanya River (site B: $18^{\circ} 15^{\prime} 08.6^{\prime \prime} \mathrm{N}$; $109^{\circ} 30^{\prime} 51.1^{\prime \prime} \mathrm{E}$ ) and Yulin Bay Hongsha (site H: $18^{\circ} 15^{\prime} 52^{\prime \prime} \mathrm{N} ; 109^{\circ} 34^{\prime} 22^{\prime \prime} \mathrm{E}$ ) nature reserves, respectively.

Three kinds of soil samples were collected: bulk soil, roots with aggregates and decomposing leaves. Soil near the plant, but not in direct contact with any root, was designated as bulk soil (BS). Soil adhered loosely to roots and obtained by hand shaking for 1 min was designated as roots with aggregates (RA). Soil near the plant and covered by decomposing leaves and litter, but not in direct contact with any root was designated as decomposing leaves (DL). In summer, the three kinds of samples were collected from site $\mathrm{H}$; in autumn, they were collected from both sites. For all samples, the top $10 \mathrm{~cm}$ of sediments with quintuplicate samples (over $1 \mathrm{~m}^{2}$ area) was collected and mixed thoroughly. All the roots, leaves and litter in the samples were discarded, and then the soil samples were placed in sterile collection bags. The different samples at the same site 
were collected at a distance from more than $10 \mathrm{~m}$ from each other. There were two duplicates: one for analysis of environmental parameters and one for DNA extraction. The samples for environmental parameter analysis were stored at $4{ }^{\circ} \mathrm{C}$ prior to analysis, and the environmental variables including total organic carbon (OC), total nitrogen (TN), available soil phosphorus (AP), available soil potassium (AK) and $\mathrm{pH}$ were measured according to Bao (1999). The samples for DNA extraction were stored at $-20{ }^{\circ} \mathrm{C}$ prior to analysis.

Total community DNA was extracted from 1.0 $\mathrm{g}$ of wet samples using the E.Z.N.A.Soil DNA Kit (Omega Bio-tek) with some modification. To remove the inhibitors such as humic acids, a pre-extraction removal strategy was carried out according to $\mathrm{Xi}$ et al., (2006). The inhibitor removal buffer ( $\mathrm{pH}$ 8.0) contained $(100 \mathrm{mM})$ Tris-HCl, $(100 \mathrm{mM})$ EDTA, $(100 \mathrm{mM}) \mathrm{Na}_{4} \mathrm{P}_{2} \mathrm{O}_{7},(100 \mathrm{mM}) \mathrm{NaCl},(1.0 \%) \mathrm{PVP}$, $(0.05 \%)$ Triton $\mathrm{X}-100$ and $(4.0 \%)$ skim milk. The humic acids were washed out from the mangrove sediment samples successfully. Total DNA extractions were performed as recommended by the manufacturer (Omega Bio-tek). The precipitated DNA was resuspended in $20 \mu \mathrm{l}$ of TE buffer $(10 \mathrm{mM}$ Tris$\mathrm{HCl}, 1 \mathrm{mM} \mathrm{Na} \mathrm{N}_{2}$ EDTA, pH 8.0). For PCR purposes, the DNA concentration was measured spectrophotometrically (HITACHI) and adjusted to a concentra-

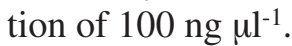

Hot start PCR was used for 16S rRNA gene amplification using a PTC-200 thermal cycler (MJ Research). PCR was performed using primers $338 \mathrm{~F}$ (5'-CCTACGGGAGGCAGCAG-3') and 518R (5'-ATTACCGCGGCTGCTGG-3') to amplify bacterial 16S rRNA gene-V3 segments. A $40 \mathrm{bp}$ GC-clamp (cgc ccg ccg cgc gcg gcg ggc ggg gcg ggg gca cgg ggg g) was added to primer $338 \mathrm{~F}$ to increase the separation of DNA bands in DGGE gel (Muyzer et al., 1993). The PCR was carried out in $50 \mu \mathrm{l}$ volumes, containing $1 \mu \mathrm{l}$ DNA template, $1 \times \mathrm{Ex}$ TaqTM Buffer, $4.95 \mathrm{mg} \mathrm{ml}^{-1} \mathrm{BSA}, 100 \mu \mathrm{M}$ dNTP, $0.2 \mu \mathrm{M}$ of each primer and $2 \mathrm{U}$ Ex TaqTM. The Taq polymerase, dNTPs and PCR buffer were purchased from TaKaRa (TaKaRa Schuzo Co., Ltd., Biomedical Group, Japan). The thermal PCR profile was as follows: initial denaturation at $95^{\circ} \mathrm{C}$ for $5 \mathrm{~min}$ followed by 30 cycles of primer annealing at $55^{\circ} \mathrm{C}$ for $30 \mathrm{~s}$, chain extension for $30 \mathrm{~s}$ at $72^{\circ} \mathrm{C}$, denaturation for $30 \mathrm{~s}$ at $94^{\circ} \mathrm{C}$ and a final extension at $72^{\circ} \mathrm{C}$ for 10 min. To reduce possible inter-sample PCR variation, all PCR reactions were run in triplicate and pooled together before loading on DGGE gel. PCR products were analysed by electrophoresis in $2 \%$ agarose gels and ethidium bromide staining.

DGGE was performed using the Dcode universal mutation detection system as described in the manufacturer's manual (Bio-Rad, Hercules, CA, USA). Approximately $300 \mathrm{ng}$ PCR products were loaded onto $8 \%(\mathrm{wt} / \mathrm{vol})$ polyacrylamide gels in $1 \times \mathrm{TAE}$ (40 $\mathrm{mM}$ Tris, $20 \mathrm{mM}$ acetate, $1.0 \mathrm{mM} \mathrm{Na} \mathrm{N}_{2}$-EDTA) with denaturant-gradient of $45-70 \%$ (100\% denaturant was $7 \mathrm{M}$ urea and $40 \%$ (wt/vol) deionised formamide). The gels were electrophoresed at a constant voltage of $100 \mathrm{~V}$ and $60{ }^{\circ} \mathrm{C}$ for $10 \mathrm{~h}$. After electrophoresis, the DGGE gels were stained with ethidium bromide and visualised under UV light in an AlphaImager imaging system (Alpha innotech).

The major dense DGGE bands were excised from the gel, resuspended in $20 \mu \mathrm{L}$ of TE buffer (10 mM Tris and $1 \mathrm{mM}$ EDTA, pH 8.0) and left at $4^{\circ} \mathrm{C}$ overnight. The supernatant after centrifugation (12000 rpm, $5 \mathrm{~min}, 4^{\circ} \mathrm{C}$ ) was used as a template. Subsequently, 16S rRNA gene-V3 segments were amplified using the 338F and 518R primer pairs with GC-clamp, and was loaded again in a DGGE gel to confirm the position of the bands. Then 16S rRNA gene-V3 segments were amplified using the 338F and 518R primer pairs without GC-clamp, and the PCR product was purified with a PCR purification kit (Tiangen) and subsequently cloned into PMD18$\mathrm{T}$ plasmid vector and Escherichia coli $\mathrm{DH} \alpha$ cells using the PMD18-T cloning vector kit according to the manufacturer's instructions (Takara). Positive recombinants were then submitted for sequencing using an ABI3730 DNA Sequencer (USA) with M13 primer at the Shanghai Invitrogen Biotech Co. Ltd. Nucleotide sequences were compared with those in the GenBank database by BLAST algorithm for tentative identifications. Phylogenetic trees of $16 \mathrm{~S}$ rRNA gene-V3 partial sequences were generated using the neighbor-joining algorithms in Mega II software. The level of support for the phylogenies derived from neighbor-joining analysis was gauged by 1000 bootstrap replicates.

DGGE digital images were analysed by the Gel Doc 2000 Quantity-One 4.5.2 gel documentation system (Bio-Rad, USA) to generate a densitometric profile. The peak areas of the fingerprint patterns were used to indicate the intensities. The bands were detected when the relative peak area to total peak area exceeded $1 \%$. The Shannon index of bacterial diversity (Shannon and Weaver, 1963) and dissimi- 
larity indices (Mouser et al., 2005) were analysed according to the DGGE band profiles.

To assess changes in the genetic diversity of bacterial communities in different mangrove samples, DGGE banding patterns were analysed by multidimensional scaling (MDS) analysis (Muckian et al., 2007). For this purpose, the dissimilarity indices were recorded in a binary matrix, which was then analysed with the program SPSS 15.0 for Windows. The resulting graphical representation, MDS map, showed every band pattern as one plot, and relative changes in community structure were visualised and interpreted as the distance among the plots. The closer the plots were to each other, the more similar were the DGGE banding patterns. Canonical correspondence analysis (CCA) (CANOCO 4.5; Biometris, Wageningen, the Netherlands) was performed on a statistical analysis of the DGGE profiles versus the environmental variables. The resulting ordination biplot approximated the weighted average of each species (in this case, band intensities) with respect to environmental variables, which were represented as arrows. The length of these arrows indicated the relative importance of that environmental factor in explaining variation in bacterial profiles, while the angle between the arrows indicated the degree to which they were correlated. A Monte-Carlo permutation test based on 199 random permutations was used to test the null hypothesis that bacterial profiles were unrelated to environmental variables.

\section{RESULTS}

\section{Environmental parameters and DGGE patterns of different samples}

The basic properties of the soil samples are shown in Table 1. The variabilities of these parameters in the different samples were obvious. For example, the $\mathrm{OC}$ concentration of samples $\mathrm{SH} 3$ ( $\mathrm{SH}=$ Summer site $\mathrm{H})$ and $\mathrm{AB} 5(\mathrm{AB}=$ Autumn site $\mathrm{B})$ was higher than that of the others, whereas the AK of sample SH3 was lower than that of the others. Figure 1 shows the bacterial community structure of different sediment samples. The banding patterns among all the samples were distinct. Analysis of DGGE gel (Fig 1.) resulted in a total of 338 detectable bands in 103 different positions (Table 2). The number of bands per sample varied between 24 and 29 (mean 26), indicating a diverse bacterial assemblage in
TABLE 1. - Main characteristics of the soil samples (value are given as mean, $n=3$ ).

\begin{tabular}{lcccccc}
\hline Samples & $\begin{array}{c}\mathrm{OC} \\
\left(\mathrm{g} \mathrm{kg}^{-1}\right)\end{array}$ & $\begin{array}{c}\mathrm{TN} \\
\left(\mathrm{g} \mathrm{kg}^{-1}\right)\end{array}$ & $\begin{array}{c}\mathrm{AP} \\
\left(\mathrm{mg} \mathrm{kg}^{-1}\right)\end{array}$ & $\begin{array}{c}\mathrm{AK} \\
\left(\mathrm{mg} \mathrm{kg}^{-1}\right)\end{array}$ & $\mathrm{pH}$ & $\begin{array}{c}\text { Sample } \\
\text { kind }\end{array}$ \\
\hline SH1 & 28.9 & 0.90 & 26.7 & 284.3 & 6.50 & RA \\
SH2 & 55.8 & 1.25 & 18.5 & 304.4 & 6.85 & $\mathrm{DL}$ \\
SH3 & 102.8 & 0.87 & 22.5 & 225.6 & 5.02 & BS \\
SH4 & 51.2 & 1.26 & 22.49 & 479.6 & 2.68 & DL \\
SH5 & 23.8 & 0.95 & 10.27 & 288.6 & 4.73 & BS \\
AH1 & 35.0 & 0.78 & 28.9 & 258.6 & 4.65 & DL \\
AH2 & 37.5 & 0.86 & 27.4 & 276.3 & 4.40 & BS \\
AH3 & 43.2 & 1.33 & 39.8 & 370.5 & 5.22 & RA \\
AB1 & 36.2 & 1.60 & 4.89 & 436.5 & 3.65 & RA \\
AB2 & 49.7 & 1.14 & 11.99 & 259.7 & 3.8 & BS \\
AB3 & 56.9 & 1.29 & 27.8 & 432 & 4.39 & BS \\
AB4 & 26.3 & 1.84 & 12.63 & 295.6 & 2.96 & RA \\
AB5 & 122.3 & 1.02 & 10.98 & 268 & 3.86 & DL \\
\hline
\end{tabular}

mangrove sediments. A total of 17 bands was excised and successfully sequenced (see number and position in Fig 1.). The indices of $H$, reflecting the structural diversity of the bacterial community, were calculated on the basis of the number and relative intensities of bands on the gel track (Table 3). Based on Table 3, the Shannon index of samples ranked $\mathrm{AH}>\mathrm{SH}>\mathrm{AB}(\mathrm{AH}=$ Autumn site $\mathrm{H})$ among collected site and seasons, whereas the species abundance ranked $\mathrm{SH}>\mathrm{AH}>\mathrm{AB}$. The results suggested that site $\mathrm{H}$ had a higher Shannon index and more microbial species than site B during our investigation. At site $\mathrm{H}$, there was a higher Shannon index in autumn and more microbial species in summer. When we compared the difference among the sample types, the Shannon index of samples ranked $\mathrm{RA}>\mathrm{DL}>\mathrm{BS}$, but the species abundance ranked DL $>$ RA $>B S$. The results indicated that the samples collected from roots with aggregate had the highest Shannon index, and the samples collected from the soil near the plant and covered by decomposing leaves and litter had the most microbial species. The samples collected from soil near the plant, but not in direct contact with any root, had the lowest Shannon index and the fewest microbial species.

\section{MDS analysis of DGGE banding pattern}

To compare broad-scale differences between bacterial community profiles, a multidimensional scaling (MDS) approach was employed to analyse DGGE banding patterns. Two-dimensional plots of MDS scores for mangrove samples are depicted in Figure 2. The results revealed that profiles from site $\mathrm{B}$ in autumn were differentiated from those from site $\mathrm{H}$ in autumn, with an MDS stress value 
TABLE 2. - All the bands recovered on the DGGE gel of the samples collected from Site H in Summer (SH 1-5) and in Autumn (AH 1-3), and from Site B in Autumn (AB 1-5). The bands that were sequenced were in bold type. Black (+): presence, white (-): absence.

\begin{tabular}{|c|c|c|c|c|c|c|c|c|c|c|c|c|c|}
\hline & SH1 & $\mathrm{SH} 2$ & $\mathrm{SH} 3$ & SH4 & SH5 & AH1 & $\mathrm{AH} 2$ & $\mathrm{AH} 3$ & $\mathrm{AB} 1$ & $\mathrm{AB} 2$ & $\mathrm{AB} 3$ & AB4 & AB5 \\
\hline $\mathrm{r} 1$ & - & - & + & + & + & - & + & - & + & + & - & - & + \\
\hline S12 & + & + & - & + & - & - & - & - & + & - & + & + & - \\
\hline r3 & - & - & - & - & - & + & - & - & - & - & - & - & - \\
\hline r4 & - & - & - & - & - & - & - & + & - & - & - & - & - \\
\hline r5 & + & + & - & + & - & + & + & - & + & + & - & - & - \\
\hline r6 & - & - & - & - & $\overline{-}$ & - & - & - & - & - & - & - & + \\
\hline r7 & - & $\overline{-}$ & + & + & + & - & - & - & - & - & - & - & - \\
\hline r8 & $\bar{t}$ & + & - & - & - & & - & - & - & - & - & + & + \\
\hline r9 & + & 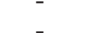 & - & - & - & + & + & + & - & - & + & - & - \\
\hline r10 & - & - & - & & - & & - & - & + & - & - & - & - \\
\hline r11 & - & - & + & - & - & + & - & + & - & - & - & - & - \\
\hline r12 & + & + & - & + & - & - & + & - & + & - & - & + & + \\
\hline r13 & - & - & - & - & + & - & - & - & - & - & - & - & - \\
\hline S14 & - & - & + & + & - & + & - & + & - & + & + & + & + \\
\hline r15 & + & + & - & - & - & - & - & - & + & - & - & - & - \\
\hline r16 & - & - & - & + & + & + & + & - & - & - & + & - & - \\
\hline r17 & + & - & + & - & - & - & - & - & + & + & - & - & + \\
\hline r18 & - & + & - & - & + & - & + & - & - & - & + & - & - \\
\hline r19 & + & + & + & - & - & + & - & + & - & - & - & - & + \\
\hline $\mathrm{r} 20$ & - & - & - & + & - & - & - & - & - & - & - & - & - \\
\hline $\mathrm{r} 21$ & - & - & - & - & + & + & - & - & - & - & + & - & - \\
\hline S9 & + & + & + & + & - & - & + & - & + & + & - & - & - \\
\hline $\mathrm{r} 23$ & + & - & - & - & + & + & - & - & - & - & + & + & + \\
\hline r24 & - & - & - & + & - & - & - & - & - & - & - & - & - \\
\hline $\mathrm{r} 25$ & - & + & + & - & - & - & - & + & - & - & - & + & - \\
\hline r26 & + & - & - & - & + & - & + & - & + & + & + & - & - \\
\hline r27 & - & - & - & - & - & + & - & - & - & - & - & - & + \\
\hline $\mathrm{r} 28$ & - & - & - & - & - & - & - & + & - & - & - & - & - \\
\hline $\mathrm{r} 29$ & - & - & + & + & - & - & - & - & + & - & - & + & - \\
\hline S1 & + & + & - & - & + & + & + & + & - & + & + & - & - \\
\hline r31 & - & - & + & - & - & - & - & - & - & - & - & - & - \\
\hline r32 & - & - & - & + & - & - & - & - & - & - & - & - & + \\
\hline S8 & - & + & + & - & - & - & - & - & - & - & - & + & - \\
\hline S11 & - & - & - & - & + & + & - & + & - & + & + & - & - \\
\hline r35 & + & - & - & - & - & - & - & - & - & - & - & - & - \\
\hline r36 & - & + & - & + & - & - & - & - & - & - & - & + & + \\
\hline r37 & - & + & - & - & + & - & - & - & - & - & + & - & - \\
\hline r38 & - & - & - & - & - & - & - & - & - & - & - & - & + \\
\hline S2 & + & + & + & + & - & - & + & - & - & - & + & + & - \\
\hline S19 & - & - & - & - & - & - & - & + & - & + & - & - & + \\
\hline r41 & - & - & + & - & + & - & - & - & + & - & - & - & - \\
\hline $\mathrm{r} 42$ & - & - & - & + & - & + & - & - & + & - & + & + & + \\
\hline r43 & - & - & - & - & - & - & - & + & - & - & - & - & - \\
\hline $\mathrm{r} 44$ & + & + & + & + & - & - & + & - & - & + & - & - & + \\
\hline r45 & - & - & - & - & + & + & - & - & - & + & + & - & - \\
\hline r46 & - & - & + & - & - & - & - & - & - & - & - & - & - \\
\hline $\mathrm{r} 47$ & - & + & - & + & - & - & - & + & - & - & - & - & - \\
\hline $\mathrm{r} 48$ & + & - & - & - & - & - & - & - & - & - & - & + & + \\
\hline S20 & - & - & - & - & + & + & + & + & - & + & + & - & + \\
\hline $\mathrm{r} 50$ & + & + & + & + & - & - & - & + & + & - & - & - & - \\
\hline r51 & - & - & - & - & - & - & - & - & - & + & - & + & - \\
\hline r 52 & - & - & - & - & + & + & + & + & + & - & + & - & - \\
\hline S3 & + & + & + & + & - & - & - & - & - & - & - & + & + \\
\hline r54 & - & - & - & - & - & - & - & - & - & + & - & - & - \\
\hline r55 & - & - & - & - & - & - & + & + & + & - & + & - & - \\
\hline r56 & + & - & - & - & + & + & + & - & - & - & - & + & - \\
\hline r57 & - & - & + & - & - & - & - & - & - & - & - & - & - \\
\hline r58 & - & + & - & - & - & - & - & - & - & - & - & - & - \\
\hline S21 & - & - & - & - & + & - & - & + & + & - & - & - & + \\
\hline r60 & + & - & - & - & - & + & - & - & - & - & - & - & - \\
\hline S15 & + & + & + & + & - & - & - & + & - & + & + & + & + \\
\hline r62 & - & - & - & - & - & + & + & - & + & - & - & - & - \\
\hline $\begin{array}{l}\text { r63 } \\
\text { to }\end{array}$ & - & - & - & - & - & - & - & - & - & - & - & - & + \\
\hline r64 & - & - & - & + & - & - & - & - & - & + & - & + & - \\
\hline S22 & - & - & - & - & + & - & - & - & + & - & + & - & - \\
\hline S18 & + & + & + & - & + & - & - & + & - & - & - & - & - \\
\hline S17 & - & - & - & + & - & + & + & + & - & - & + & + & - \\
\hline r68 & - & - & - & - & - & - & - & - & - & - & - & - & + \\
\hline r69 & - & - & - & + & - & - & - & - & - & + & - & - & - \\
\hline S4 & + & + & + & - & + & + & + & - & - & - & + & - & + \\
\hline
\end{tabular}


TABLE 2 (cont.). - All the bands recovered on the DGGE gel of the samples collected from Site H in Summer (SH 1-5) and in Autumn (AH 1-3), and from Site B in Autumn (AB 1-5). The bands that were sequenced were in bold type. Black (+): presence, white (-): absence.

\begin{tabular}{|c|c|c|c|c|c|c|c|c|c|c|c|c|c|}
\hline & SH1 & SH2 & SH3 & SH4 & SH5 & AH1 & $\mathrm{AH} 2$ & $\mathrm{AH} 3$ & $\mathrm{AB} 1$ & $\mathrm{AB} 2$ & AB3 & AB4 & AB5 \\
\hline r71 & + & - & - & - & - & - & + & - & + & + & - & - & - \\
\hline r72 & - & - & - & - & - & - & - & - & - & - & - & + & - \\
\hline r73 & - & - & - & - & + & - & - & - & - & - & - & - & - \\
\hline S13 & - & - & + & + & - & - & - & + & + & + & - & - & - \\
\hline $\begin{array}{r}\text { r75 } \\
r 76\end{array}$ & + & - & + & - & - & + & - & + & - & - & - & - & - \\
\hline $\begin{array}{l}\text { r76 } \\
\text { r77 }\end{array}$ & - & - & - & - & + & - & + & - & + & - & - & + & - \\
\hline $\begin{array}{l}\text { r78 } \\
\text { lat }\end{array}$ & - & - & + & + & - & + & - & + & - & - & + & - & + \\
\hline r79 & - & + & - & - & - & - & - & - & - & - & - & - & - \\
\hline r80 & + & - & - & - & - & - & - & - & - & - & - & - & - \\
\hline r81 & - & - & - & - & - & + & - & - & - & - & + & + & + \\
\hline r82 & - & - & - & - & - & - & - & - & - & + & - & - & - \\
\hline r83 & - & - & - & - & + & - & - & - & - & - & - & - & - \\
\hline r84 & - & - & - & - & - & + & - & - & - & - & - & + & - \\
\hline r85 & + & + & + & - & - & - & + & - & - & + & + & - & - \\
\hline r86 & - & - & & + & - & + & - & - & - & - & - & - & - \\
\hline r87 & - & - & - & - & - & + & - & - & - & - & - & - & - \\
\hline r88 & - & - & - & - & - & - & + & - & + & + & - & - & - \\
\hline r89 & - & - & - & - & - & - & - & - & - & - & + & - & - \\
\hline r90 & - & - & + & + & - & - & - & + & - & - & - & - & + \\
\hline r91 & + & + & - & - & - & - & - & - & - & - & - & + & - \\
\hline r92 & - & - & - & - & - & - & - & - & + & + & - & - & + \\
\hline r93 & - & - & - & - & - & - & + & - & - & - & - & - & - \\
\hline r94 & - & - & - & - & - & - & - & + & - & - & - & - & - \\
\hline $\begin{array}{l}\mathrm{r} 95 \\
\text { to }\end{array}$ & - & - & + & - & - & - & - & - & - & - & - & + & - \\
\hline r96 & - & + & - & - & - & + & - & - & - & - & - & - & + \\
\hline r97 & - & - & - & - & + & - & - & - & - & - & - & - & - \\
\hline r98 & - & - & - & - & - & - & - & - & + & - & - & - & - \\
\hline r99 & + & - & - & - & - & - & + & - & - & - & - & - & - \\
\hline r100 & - & - & + & - & - & - & - & - & - & - & - & - & - \\
\hline r101 & - & + & - & + & - & - & - & - & - & - & - & - & - \\
\hline r102 & + & - & - & - & - & - & - & - & - & - & - & - & - \\
\hline r103 & - & - & - & - & - & - & - & - & - & + & - & - & - \\
\hline
\end{tabular}

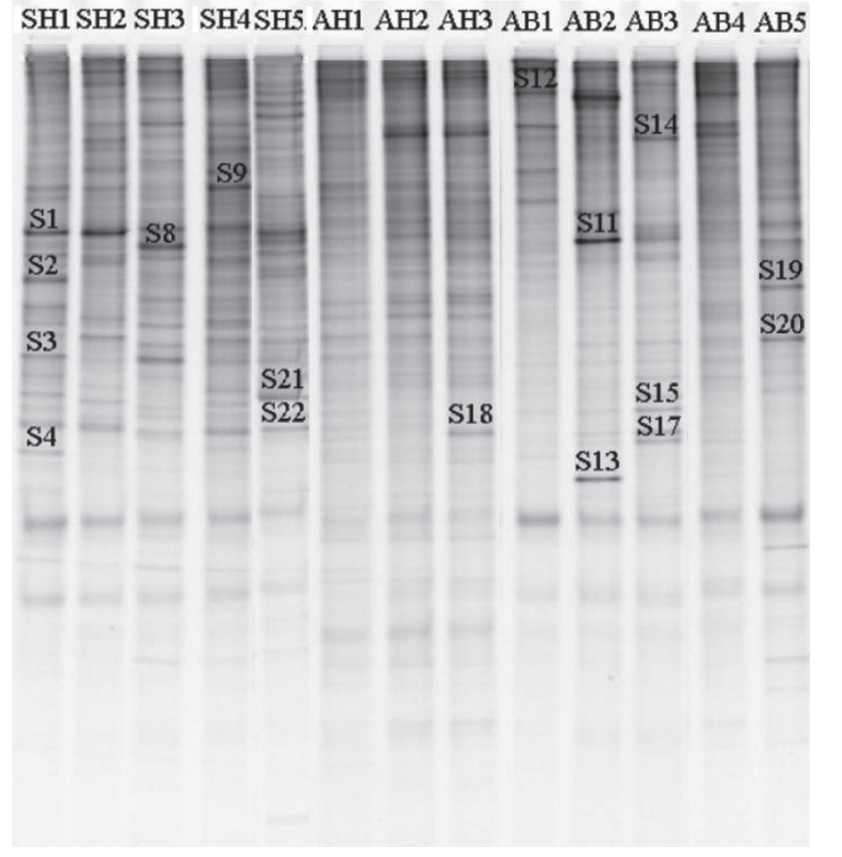

FIG. 1. - DGGE gels showing diversity of 16S rRNA gene fragments of the samples collected from Site $\mathrm{H}$ in summer (SH 1-5) and in autumn (AH 1-3), from Site B in autumn (AB 1-5). Lanes are labelled with sample numbers. Numbers on gels are the bands that were excised and sequenced and correspond to the list in Table 4.
TABLE 3. - Comparison of the microbial diversity of mangrove samples (the $H$ was calculated on the basis of the number and relative intensities of bands on the gel track).

samples Shannon-weaver index $(H) \quad$ DGGE bands number

\begin{tabular}{lll}
\hline SH1 & 1.293 & 29 \\
SH2 & 1.292 & 27 \\
SH3 & 1.078 & 28 \\
SH4 & 1.319 & 28 \\
SH5 & 1.251 & 24 \\
AH1 & 1.378 & 28 \\
AH2 & 1.148 & 24 \\
AH3 & 1.238 & 25 \\
AB1 & 1.229 & 24 \\
AB2 & 1.237 & 24 \\
AB3 & 1.304 & 25 \\
AB4 & 1.272 & 24 \\
AB5 & 1.039 & 28 \\
\hline
\end{tabular}

of 0.17 (stress values of below 0.2 indicate that an MDS ordination plot is a good spatial representation of differences between data). The banding pattern of samples $\mathrm{SH} 3$ and AB5 were scattered from the other plots. Overall, MDS ordination plots indicated that the composition of bacterial communities varied with sampling sites and sampling time. Mangrove 


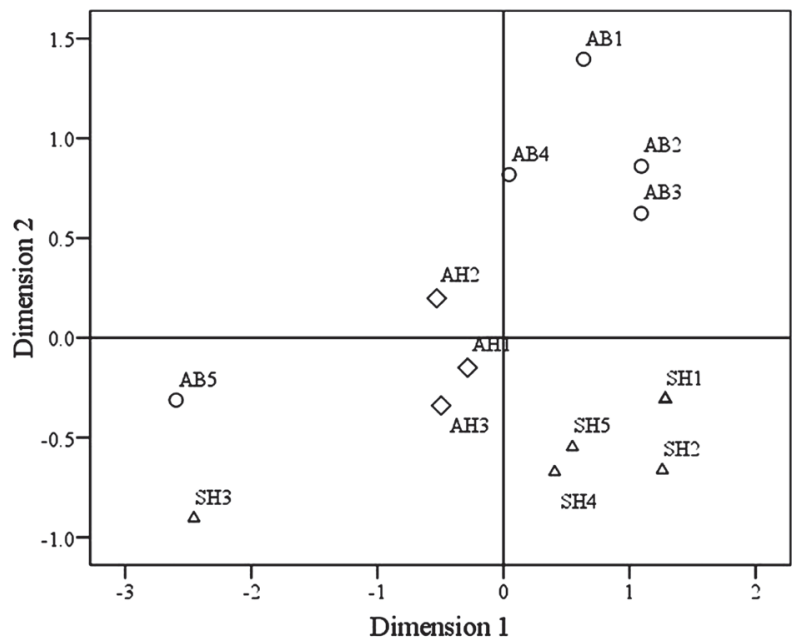

FIG. 2. - Two-dimensional plots of MDS analysis from DGGE patterns to compare broad-scale differences between bacterial community profiles of different mangrove samples (the MDS analysis was based on dissimilarity indices $(D)$ and $D$ was given by:

$$
D_{A B}=\sqrt{\sum_{i=1}^{P}(A i-B i)^{2}},
$$

$A_{i}$ : importance probability of each band on gel lane A. No band is treated as zero. $B_{i}$ : importance probability of each band on gel lane $\mathrm{B}$. No band is treated as zero. $P$ : (total number of bands on lane A) + (total number of bands on lane B) - (total number of bands common to lane $\mathrm{A}$ and lane B).

samples collected from the same site and in the same time had more similar microbial communities, except samples SH3 and AB5.

\section{Microbial community composition in relation to environmental variables}

Multivariate statistical analysis was used to explore the relationships between environmental factors and the members of bacterial communities in more detail. Canonical correspondence analysis was carried out using abundant bacterial phylotypes (at least detected in three samples) within datasets together with environmental variables (Muckian et al., 2007). Eigenvalues (indicating strength of the model) for the first two multivariate axes were 0.474 and 0.354 . The sum of all canonical eigenvalues was 1.506. Axes 1 and 2 were found to explain $31.5 \%$ and $23.5 \%$ of the overall variance, respectively, indicating a strong gradient in the data set. Species environment correlations for both axes were more than 0.94, suggesting that bacterial phylotypes were strongly correlated with environmental factors. Monte-Carlo significance tests indicated that both axes explained a significant proportion of the variation in the data. The first axis was significantly correlated with OC $(P<0.01)$, indicating that the first axis mainly showed the gradient

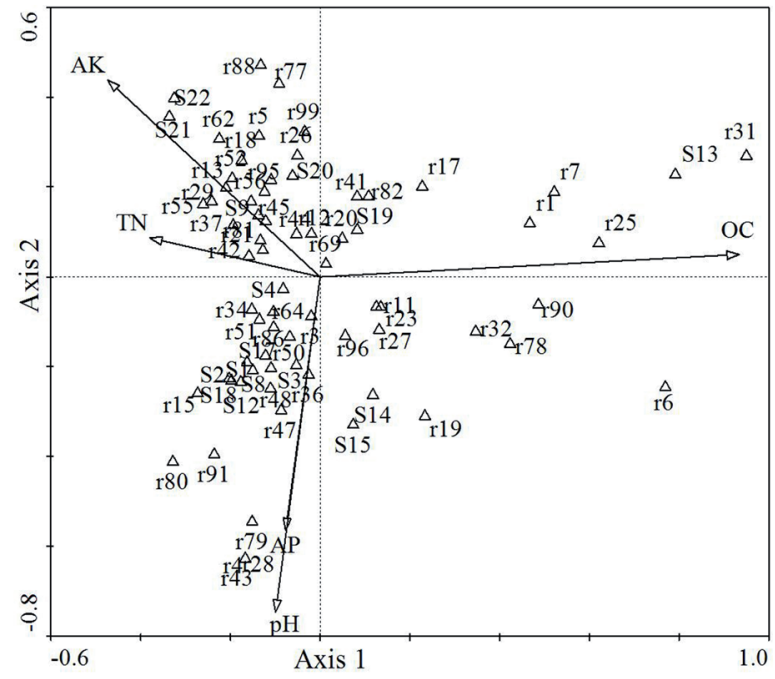

FIG. 3. - Canonical correspondence analysis (CCA) ordination diagram of DGGE data, with environmental factors as arrows $(\mathrm{AK}=$ available soil potassium, $\mathrm{TN}=$ total nitrogen, $\mathrm{OC}=$ total organic carbon content, AP = available soil phosphorus), and individual abundant bacterial phylotypes as triangles.

of organic carbon concentration in the mangrove sediments. The second axis was correlated with $\mathrm{pH}$ and AP $(P<0.05)$, which revealed the changes in bacterial community composition along the gradient of $\mathrm{pH}$ and available phosphate.

The CCA biplot is shown in Figure 3. Each environmental variable is represented by an arrow, which determines an axis. The projection of a taxon (indicated as open triangles) on this axis shows the level of the variable where the taxon is most abundant. More details about the interpretation of the biplot can be found in Ter Braak (1987). Based on Figure 3, it is clear that most bacterial phylotypes have a negative correlation with $\mathrm{OC}$, which was distributed on the left side of the biplot, including the sequenced bacterial phylotypes S1, S2, S3, S4, S8, S9, S12, S17, S18, S22 and $\mathbf{S} 21$ (see number and position in Fig 1.). Bacterial phylotypes S14 and S15 were negatively correlated with AK. Bacterial phylotypes S19 and S20 showed a significant negative correlation with $\mathrm{pH}$, AP. Furthermore, phylotypes r6, r78, r19, et al., showed a significant negative correlation with $\mathrm{AK}$ and TN. Bacterial phylotypes r4, r28, r43 and r79 showed a significant correlation with $\mathrm{AP}$ and $\mathrm{pH}$.

\section{Identification and phylogenetic analysis of the predominant bacterial phylotypes based on $16 \mathrm{~S}$ rRNA gene sequences}

Seventeen bands were excised from gel tracks, which were verified by DGGE three times to en- 
TABLE 4. - Summary of the 16S rRNA gene sequences obtained from the respective bands in DGGE gel and the closest match to the National Centre for Biotechnology Information (NCBI) Nucleotide Sequence database (GenBank)

\begin{tabular}{lllll}
\hline Band & Accession no. & \multicolumn{1}{c}{ Database match } & & Origin \\
\hline S1 & EF531307 & uncultured bacterium (AB099989) & inactive deep-sea hydrothermal vent chimneys \\
S2 & EF531308 & uncultured bacterium (EU499677) & freshwater sediment & 98 \\
S3 & EF531309 & Lactococcus sp. GA68 (EU260327) & tropical oligotrophic lakes & 99 \\
S4 & EF531310 & uncultured Enhydrobacter sp. (EU305591) & Sanwayao wastewater plant (WWTP) & 100 \\
S8 & EF531311 & uncultured Sphingobacteria bacterium (AY712439) & salt marsh & environmental sample \\
S9 & EF531312 & uncultured bacterium (AM234673) & wastewater & 97 \\
S11 & EF531313 & uncultured bacterium (EU234087) & mangrove soil & salt marsh \\
S12 & EF531314 & uncultured deltaproteobacterium (DQ811831) & raw cow milk & 99 \\
S13 & EF531315 & uncultured bacterium (AY710524) & salt marsh sediment & environmental samples \\
S14 & EF531316 & uncultured Streptococcus sp. (EU029521) & high-temperature volcanic environment \\
S15 & EF531317 & uncultured bacterium (EF582536) & oil-polluted marine microbial mat & 94 \\
S17 & EF531319 & uncultured bacterium (EU137496) & salt marsh & 98 \\
S18 & EF531320 & uncultured Firmicutes bacterium (EF462577) & 98 \\
S19 & EF531321 & Uncultured gammaproteobacterium (AM229469) & 99 \\
S20 & EF531322 & uncultured Flavobacteria bacterium (AY712396) & raw cow milk \\
S21 & EF531323 & uncultured Lactococcus sp. (EU029397) & indoor dust & 94 \\
S22 & EF531324 & uncultured bacterium (AM697164) & & 100 \\
& & & & 100 \\
\hline
\end{tabular}

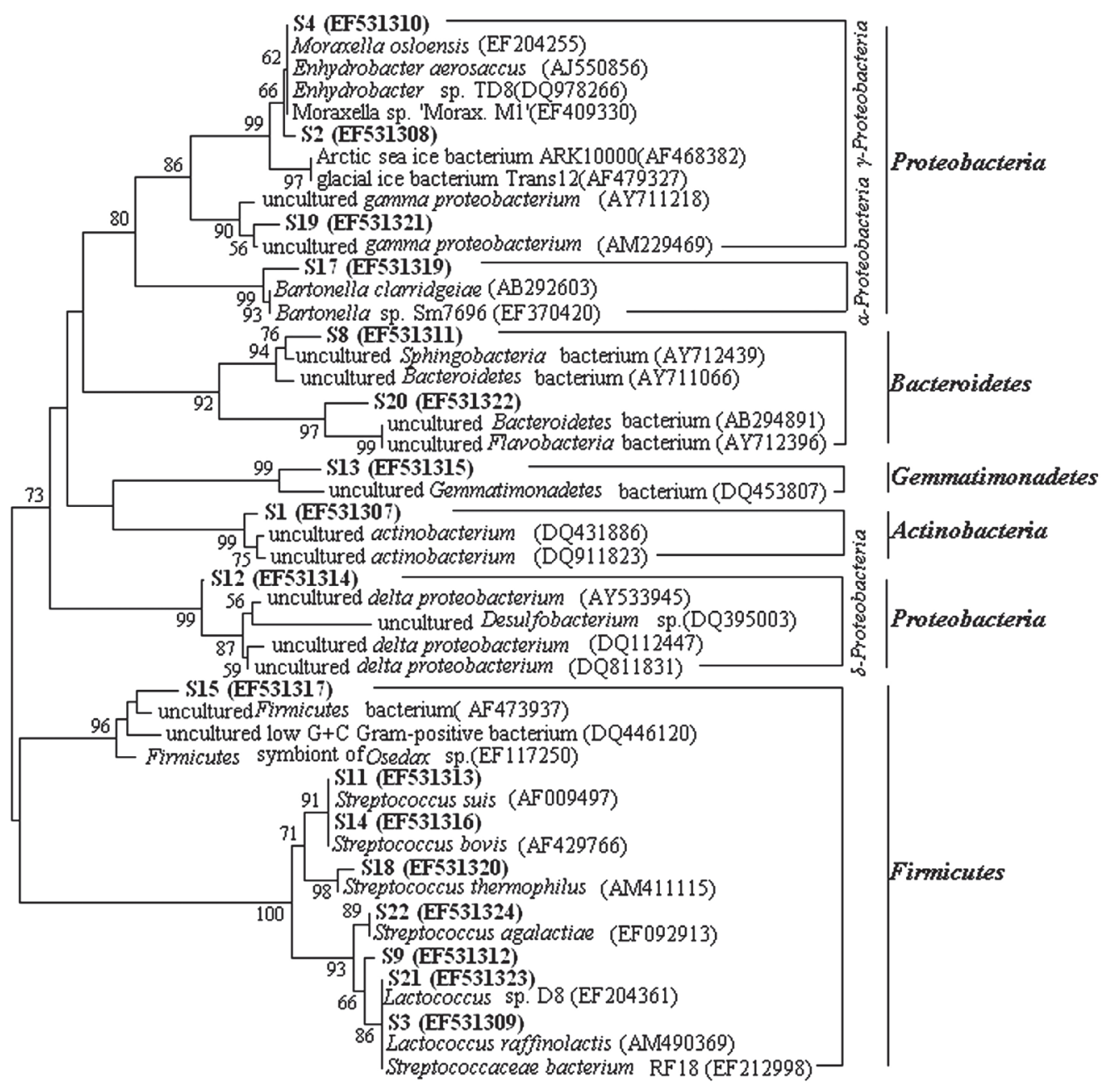

$\overleftarrow{0.02}$

FIG. 4. - Unrooted phylogenetic tree based on 16S rRNA gene-V3 sequences representing the respective DGGE bands in Figure 1. Bootstrap analysis was based on 1000 replicates. Bootstrap values from distance analysis are depicted. Bootstrap values less than $50 \%$ are not shown. Scale indicates $2 \%$ sequence divergence. 
sure a single band at the same location. Sequencing analysis of the predominant phylotypes that represents the excised DGGE bands is summarised in Table 4. All the sequences obtained in this study have been assigned to the GenBank nucleic acid sequence database with accession numbers EF531307EF531317 and EF531319-EF531324. According to Table 4 , most sequences were similar to $16 \mathrm{~S}$ rRNA gene sequences reported from uncultured organisms present in environmental samples from sources such as mangrove soil, tropical oligotrophic lakes, salt marsh sediment, wastewater, high-temperature volcanic environment, oil-polluted marine microbial mat, inactive deep-sea hydrothermal vent chimneys and freshwater sediment. (Table 4).

For phylogenetic analysis, the 16S rRNA gene sequences of the 17 clones of this study were compared with those retrieved from GenBank database. The neighbour-joining analysis divided these sequences into five main groups, Proteobacteria $(\gamma, \alpha$ and $\delta$ subdivisions), Bacteroidetes, Gemmatimonadetes, Actinobacteria and Firmicutes (Fig. 4). According to Figure 4, ten sequences have high similarity or are even identical to cultivable bacteria. Two DNA bands clustered with $\gamma$-Proteobacteria, S2 and S4, and their $16 \mathrm{~S}$ rRNA gene sequences were $>99 \%$ identical to Moraxella osloensis. In the $\alpha$-Proteobacteria cluster, band S17 had 98\% similarity with Bartonella clarridgeiae at the DNA level. In the Firmicutes cluster most sequences were assigned to the Streptococcus and Lactococcus genera. 16S rRNA gene sequences of band S11 have 99\% similarity with Streptococcus suis. Band S14 was 100\% identical to 16S rRNA gene sequences of Streptococcus bovis and Streptococcus suis. The 16S rRNA gene sequence of S18 had 99\% similarity with Streptococcus thermophilus. S22 was $100 \%$ identical to the $16 \mathrm{~S}$ rRNA gene sequence of Streptococcus agalactiae. S21, S3 and S9 were clustered together with Lactococcus raffinolactis, and had 96-100\% similarity.

However, the identity of seven DNA bands could not be verified with a strong credibility value to any defined genera in the phylogenetic analysis. All of them showed a high sequence similarity to uncultured bacterium from the GenBank database (Fig. 4). The 16S rRNA gene sequences of S19 had $96 \%$ similarity with uncultured $\gamma$-Proteobacterium retrieved from oil polluted marine microbial mat. In Bacteroidetes cluster, band S8 had $97 \%$ similarity with uncultured Sphingobacteria bacterium retrieved from Sapelo Island salt marsh samples, and band S20 had 94\% similarity with uncultured Flavobacteria bacterium retrieved from salt marsh samples. In the Gemmatimonadetes cluster, the 16S rRNA gene sequence of S13 was $88 \%$ similar to uncultured bacterium retrieved from salt marsh. In the Actinobacteria cluster, S1 had 97\% similarity with uncultured Actinobacterium retrieved from Mexico Island sediments. In the

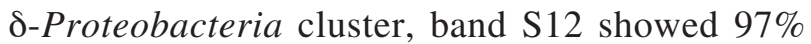
similarity with uncultured deltaproteobacterium retrieved from mangrove soil samples. The 16S rRNA gene sequence of S15 had 97\% similarity with uncultured Firmicutes bacterium associated with black band disease in coral.

\section{DISCUSSION}

Although molecular approaches for assessing the microbial diversity in natural environments have been well developed and widely used in various types of environments (Urakawa et al., 1999; Iwamoto et al., 2000; Araya et al., 2003; Bürgmann et al., 2004; Li et al., 2006; Sousa et al., 2006; Muckian et al., 2007), our knowledge of the microbiology of mangrove ecosystems is still largely based on cultivation-dependent studies (Holguin et al., 2001). Recently, the 16S rRNA gene clone library was applied to investigate the bacterial composition in Futian mangrove swamp and the results showed that the surface sediments from subtropical mangrove swamp harbored a phylogenetically diverse population of organisms from the bacteria (Liang et al., 2007). In this study, DGGE fingerprinting analysis provides an appropriate culture-independent approach for the rapid detection of the predominant microbial species and enables the simultaneous analysis of multiple samples. The banding patterns and numbers among all the samples indicated a diverse bacterial assemblage in tropical mangrove sediments.

Environmental parameters affecting the community of soil bacteria have been detailed over many years (Holguin et al., 2001). The result from Alexander (1971) showed that the presence or absence of particular culturable bacterial genera may depend on soil parameters. Although a considerable amount is known about how culturable bacteria respond to environmental variables in mangrove ecosystems (Takizaqa et al., 1993; Wu 1993; Wang and Hong 2005), little is known about how environmental variables influence the structure of 
mangrove sediment bacterial communities in situ. In this study, CCA was employed to explore how the changes in microbial community composition varied with environmental conditions, which has been proven to be sensitive in detecting the relationship between bacterial community composition and environmental parameters (Iwamoto et al., 2000; Mouser et al., 2005; Jiang et al., 2007; Zhang et al., 2008). The previous studies reported that the cultivable bacteria composition has high similarity between mangrove soils collected from different mangrove areas (Shome et al., 1995). While our results revealed that the in situ bacterial community compositions varied with different mangrove areas, and were strongly correlated with environmental factors. OC, $\mathrm{pH}$ and $\mathrm{AP}$ accounted for a significant amount of the variability in the bacterial community composition. This indicated that organic matter content, $\mathrm{pH}$ and available soil phosphors could influence the bacterial community structure in mangrove sediments. Bacteria were considered to be responsible for most of the carbon flux in tropical mangrove sediments, as they process most of the energy flow and nutrients, and act as a carbon sink (Alongi et al., 1989; Boto et al., 1979; Bano et al., 1997; Alongi 1988, 1994). In tropical mangroves the resident bacterial community consumes much of the carbon dissolved in the interstitial water (Holguin et al., 2001). Mangrove ecosystems depend on bacteria for nutrient recycling, as the nitrogen is consumed before it can be released into the atmosphere as $\mathrm{N}_{2}$ (Rivera-Monroy and Twilley, 1996). The nitrate present in sediments and originating from the degradation of nitrogenous organic compounds is probably converted to ammonium ions by bacteria and is then assimilated by plants and bacteria. In turn, the bacteria seem to benefit from their association with the mangrove trees. In terrestrial environments, bacteria colonising the surface of plant roots induce root exudates, which can stimulate microbial activity in the rhizosphere (Lynch and Whipps 1990; Holguin et al., 2001). In general, the relationship between bacteria community compositions and environmental factors were complicated in the mangrove ecosystem. Bacteria community compositions varied with environmental conditions and the variation of bacterial community composition may lead to the changes in nutrient condition in mangrove ecosystems.

In order to explore the phylogenetic and functional diversity of predominant bacteria in the man- grove habitat, the dense DGGE bands were excised and successfully sequenced. Phylogenetic analysis showed that the 17 16S rRNA gene sequences of this study clustered in various taxonomic groups, including Proteobacteria, Bacteroidetes, Gemmatimonadetes, Actinobacteria, and Firmicutes (Fig 4.). Based on our data, it appeared that the sequences clustering with the Bacteroidetes, Gemmatimonadetes and Actinobacteria group could not be verified with a strong credibility value to any defined species in the phylogetic analysis, which suggested that the bacteria in mangrove ecosystems are largely unexplored. Seven sequence phylotypes were identified with Streptococcus genera (gram-positive) of the phylum Firmicutes. Kathiresan (2003) reported that bacteria of Streptococcus genera were the predominant species of polythene and plastics-degrading microbes from the mangrove soil. Liao et al., (2007) showed that Proteobacteria prevails in bacterial communities of Brazil mangrove soils. In our results $\gamma-, \alpha$ - and $\delta$-Proteobacteria were detected in the Proteobacteria group. Proteobacteria have been suggested to play an important role in the $\mathrm{N}-, \mathrm{P}-$, and $\mathrm{S}$ - cycle in mangrove sediments, such as nitrogen fixation, phosphate solubility and sulfate reduction (Holguin et al., 2001).

In conclusion, the surface sediments of tropical mangrove ecosystems harboured a phylogenetically diverse population of bacteria. The bacterial community compositions were related to environmental parameters, and the microbial communities varied with sample collection sites and seasons. Predominant bacteria in mangrove ecosystems clustered with various taxonomic groups. Some of them are related to genera or taxa that were classically identified in mangrove sediment and expected with known functions, but many are derived from uncultivable taxa. 16S rRNA gene-DGGE fingerprinting, in combination with comprehensive multivariate statistical approaches, is particularly useful as an investigation method for distinguishing between communities and obtaining the knowledge of relationship between microbial community and environmental parameters in mangrove ecosystems.

\section{ACKNOWLEDGMENTS}

The research was supported by the Knowledge Innovation Programme of the Chinese Academy of Sciences (No. KSCX2-SW-132), the National Na- 
ture Science Fund (No.40776069; No.40676091), the Sanya Station Database and the Information System of CERN, the Field Station Fund of CAS, the China National Programme for Ocean Commonwealth (NO.200705026), the Science and Technology Programme of Guangdong Province (No.2004B60302004, 2005B60301032), the China National Key Programme for Basic Research (No.2005CCA04800), and the LMM-LAMB-LMB United Fund of the South China Sea.

\section{REFERENCES}

Alexander, M. - 1971. Microbial ecology. Wiley, New York.

Alongi, D.M. - 1988. Bacterial productivity and microbial biomass in tropical mangrove sediments. Microb. Ecol. 15: 59-79.

Alongi, D.M. - 1994. The role of bacteria in nutrient recycling in tropical mangrove and other coastal benthic ecosystems. Hydrobiologia, 285: 19-32.

Alongi, D.M., K.G. Boto and F. Tirendi. - 1989. Effect of exported mangrove litter on bacterial productivity and dissolved organic carbon fluxes in adjacent tropical nearshore sediments. Mar. Ecol. Prog. Ser., 56: 133-144

Alongi, D.M., P. Christoffersen and F. Tirendi. - 1993. The influence of forest type on microbial-nutrient relationships in tropical mangrove sediments. J. Exp. Mar. Biol. Ecol., 171: 201-223.

Amann, R.I., W. Ludwig and K.H. Schleifer - 1995. Phylogenetic identification and in situ detection of individual microbial cells without cultivation. Microbiol. Rev., 59: 143-169.

Araya, R., K. Tani, Y. Takagi, N. Yamaguchi and M. Nasu. - 2003. Bacterial activity and community composition in stream water and biofilm from an urban river determined by fluorescent in situ hybridisation and DGGE analysis. FEMS Microbiol. Ecol., 43: $111-119$

Bano, N., M.U. Nisa, N. Khan, M. Saleem, P.J. Harrison, S.I. Ahmed and F. Azam. - 1997. Significance of bacteria in the flux of organic matter in the tidal creeks of the mangrove ecosystem of the Indus river delta, Pakistan. Mar. Ecol. Prog. Ser., 157 $1-12$

Bao, S.D. - 1999. Analysis of agricultural soil. China Agriculture Press, Beijing.

Boto, K.G. - 1979. Nutrient and organic fluxes in mangroves. In: B.F. Clough (ed.), Mangrove ecosystems in Australia: structure, function and management, pp. 239-257. Colorcraft, Hong Kong.

Bürgmann, H., F. Widmer, W. Von Sigler and J. Zeyer. - 2004. New molecular screening tools for analysis of free-living diazotrophs in soil. Appl. Environ. Microbiol., 70: 240-247.

Fu, G.A. and J. Li. - 1999. Oldest and the original Sanya mangrove of Hainan Island. Tropical Forestry, 27: 16-22.

Holguin, G., M.A. Guzman and Y. Bashan. - 1992. Two new nitrogen-fixing bacteria from the rhizosphere of mangrove trees: Their isolation, identification and in vitro interaction with rhizosphere Staphylococcus sp. FEMS Microbiol. Ecol., 101: 207-216.

Holguin, G., P. Vazquez and Y. Bashan. - 2001. The role of sediment microorganisms in the productivity, conservation, and rehabilitation of mangrove ecosystems: an overview. Biol. Fertil. Soils, 33: 265-278.

Huang, L.M., S. Zhang, H.K. Wang, W.Y. Wen and Q.M. Zhang. - 2007. Ecological Environment and Bio-resources for Sanya Bay, Hainan Island, China. In: C.Y. Huang, K.L. Peng and H. $\mathrm{Xi}$ (eds.), Mangrove resources and the ecological environment. pp. 239-248. Beijing, Science Press.

Iwamoto, T., K. Tani, K. Nakamura, Y. Suzuki and M. Kitagawa. - 2000. Monitoring impact of in situ biostimulation treatment on groundwater bacterial community by DGGE. FEMS Microbiol. Ecol., 32: 129-141

Jiang, J.G., S.G. Wu and Y.F. Shen. - 2007. Effects of seasonal succession and water pollution on the protozoan community structure in a eutrophic lake. Chemosphere, 66: 523-532.

Kathiresan, K. - 2003. Polythene and plastics-degrading microbes from the mangrove soil. Rev. Biol. Trop., 51(3): 629-634.

Li, Z., L. He, J. Wu and Q. Jiang. - 2006. Bacterial community diversity associated with four marine sponges from the South China Sea based on 16S rRNA gene-DGGE fingerprinting. $J$. Exp. Mar. Biol. Ecol., 329: 75-85.

Liang, J.B., Y.Q. Chen, Y.L. Chong, N.F.Y. Tam, Q.J. Zan and L.N. Huang. -2007 . Recovery of novel bacterial diversity from mangrove sediment. Mar. Biol., 150: 739-747.

Liao, P.C., B.H. Huang and S. Huang. - 2007. Microbial community composition of the Danshui River estuary of northern Taiwan and the practicality of the phylogenetic method in microbial barcoding. Microb. Ecol., 54(3): 497-507.

Lynch, J.M. and J.M. Whipps. - 1990. Substrate flow in the rhizosphere. Plant Soil 129: 1-10.

Mo, Y.N., Z.Z. Geng and W.B. Su. - 1999. Investigation report of Haina Island mangrove. Tropical Forestry, 27: 12-15.

Mouser, P.J., D.M. Rizzo, W.F.M. Roling and B.M.A. Van Breukelen. - 2005. Multivariate statistical approach to spatial representation of groundwater contamination using hydrochemistry and microbial community profiles. Environ. Sci. Technol., 39: 7551-7559.

Muckian, L., R. Grant, E. Doyle and N. Clipson. - 2007. Bacterial community structure in soils contaminated by polycyclic aromatic hydrocarbons. Chemosphere, 68: 1535-1541.

Muyzer, G., E.C. de Waal and A.G. Uitterlinden. - 1993. Profiling of complex microbial populations by denaturing gradient gel electrophoresis analysis of polymerase chain reaction-amplified genes coding for 16S rRNA. Appl. Environ. Microbiol., 59: 695-700.

Rivera-Monroy, V.H. and R.R. Twilley. -1996. The relative role of denitrification and immobilization in the fate of inorganic nitrogen in mangrove sediments (Términos Lagoon, Mexico). Limnol. Oceanogr., 41: 284-296.

Sengupta, A. and S. Chaudhuri. - 1991. Ecology of heterotrophic dinitrogen fixation in the rhizosphere of mangrove plant community at the Ganges river estuary in India. Oecologia, 87(4): 560-564.

Shannon, C.E. and W. Weaver. - 1963. The Mathematical Theory of Communication. University of Illinois Press, Urbana and Chicago, USA.

Shome, R., B.R. Shome, A.B. Mandal and A.K. Bandopadhyay. - 1995. Bacterial flora in mangroves of Andaman-Prat 1: Isolation, identification and antibiogram studies. Indian J. Mar. Sci., 24: 97-98.

Sousa, O.V., A. Macrae, F.G.R. Menezes, N.C.M. Gomes, R.H.S.F. Vieira and L.C.S. Mendonca-Hagler. - 2006. The impact of shrimp farming effluent on bacterial communities in mangrove waters, Ceara, Brazil. Mar. Pollut. Bull., 52(12): 1725-1734

Staley, J.T. and A. Konopka. - 1985. Measurement of in situ activities of nonphotosynthetic microorganisms in aquatic and terrestrial habitats. Anпи. Rev. Microbiol., 39: 321-346.

Takizaqa, M., R.R. Colwell and R.T. Hill. - 1993. Isolation and diversity of actinomycetes in the Chesapeake Bay. Appl. Environ. Microbiol., 59(4): 997-1002.

Ter Braak, C.J.F. - 1987. The analysis of vegetation-environment relationships by canonical correspondence analysis. Vegetation, 69: 69-77.

Urakawa, H., K. Kita-Tsukamoto and K. Ohwada. - 1999. Microbial diversity in marine sediments from Sagami Bay and Tokyo Bay, Japan, as determined by 16S rRNA gene analysis. Microbiol., 145: 3305-3315.

Vazquez, P., G. Holguin, M.E. Puente, A. Lopez-Cortes and Y. Bashan. - 2000. Phosphate-solubilizing microorganisms associated with the rhizosphere of mangroves in a semiarid coastal lagoon. Biol. Fertil. Soils, 30: 460-468.

Wang, Y. and K. Hong. - 2005. Effects of soil factors on microbe distributions in mangrove soil. Chin. J. Trop. Crops, 26(3): $109-114$.

Wu, R.W. - 1993. Studies in the microbial flora of the Tansui River Mangrove forest. Inst. Bot., Acad. Sinia Monograph Ser., 13: 303-317.

Xi, F., L. Fu, G. Wang and T. Zheng. - 2006. A simple method for removing humic acids from marine sediment samples prior to DNA extraction. High Tech. Lett., 16(5): 539-544. 
$498 \cdot$ Y. ZHANG et al.

Zhang, Y.Y., J.J. Dong, Z.H. Yang, S. Zhang and Y.S. Wang. - 2008. Phylogenetic diversity of nitrogen-fixing bacteria in mangrove sediments assessed by PCR-Denat

using Gradient Gel Electrophoresis. Arch. Microbiol., 190: 19-28.
Scient. ed.: D. Vaqué.

Received April 17, 2008. Accepted November 25, 2008

Published online April 14, 2009. 